\title{
PRODUCTION AND CHARACTERIZATION OF MONOCLONAL AND POLYCLONAL ANTIBODY AGAINST RECOMBINANT OUTER MEMBRANE PROTEIN
}

\author{
${ }^{1}$ Mahdi Fasihi-Ramandi, ${ }^{1}$ Amir Nedjad-Moghaddam, ${ }^{1}$ Fatemeh Arabsalmany, \\ ${ }^{1}$ Soghra Asgari, ${ }^{2}$ Sajjad Ahmadi-Renani and ${ }^{1}$ Kazem Ahmadi \\ ${ }^{1}$ Molecular Biology Research Center, Baqiyatallah University of Medical Sciences, Tehran, Iran \\ ${ }^{2}$ Tehran University of Medical Sciences, Tehran, Iran
}

Received 2014-04-04; Revised 2014-04-07; Accepted 2014-04-26

\begin{abstract}
There are many studies related to immunological and molecular methods for diagnosis of Vibrio cholera (V. cholerae). However, most assays dependent on enrichment of culture of bacteria, which need more time and involves the use of costly equipment and reagents. In this study Balb/c mice were immunized with recombinant Outer Membrane Protein (rOMPw) of vibrio cholerae and splenocytes of hyper immunized mice were fused with murine myeloma Sp2/0 cells. Positive hybridomas were selected by ELISA using rOMPw as coating antigen. The monoclonal antibodies from ascitic fluids were purified and its reaction with rOMPw was assessed by ELISA. Polyclonal antibodies were also produced by immunization of rabbits with the above mentioned antigen. The rabbit sera was affinity purified using Hi-Trap protein $\mathrm{G}$ column. The result showed that monoclonal antibody specific to rOMPw has been successfully generated. The monoclonal antibody reacted with recombinant OMPw in ELISA and immunonoblat method. Rabbit polyclonal antibody was also bound to rOMPw by ELISA. The results of agglutination test with whole bacteria also showed that both mouse monoclonal and rabbit polyclonal antibodies reacted with whole vibrio cholera but not other related bacteria. The purpose of this study was to check out if anti OMPw antibodies could use as diagnostic assay for detection of $V$. cholerae. Our results demonstrated that anti recombinant $\mathrm{OMPw}$ monoclonal and polyclonal antibodies are able to diagnose whole bacteria in pure culture using agglutination test but not by home made immunochromatic strip test.
\end{abstract}

Keywords: Vibrio Cholerae, OMPw, Monoclonal Antibody

\section{INTRODUCTION}

Among numerous outer membrane proteins of Vibrio cholerae ( $V$. cholerae), which are vary in their abundance and immunogenicity, the $22 \mathrm{KDa}$ Outer Membrane Protein (OMPw) has been reported to be very immunogenic. This protein which is produced in minor amounts, its function is not well known, but may use as a diagnostic indicator of $V$. cholerae. The effective and rapid method for detection of $V$. cholerae is required for control of epidemic outbreaks. Traditional identification of $V$. cholerae is often achieved through the isolation of Corresponding Author: Kazem Ahmadi, Molecular Biology Tehran, Iran Tel: 009821-26127258 the bacteria and time-consuming, laborious routine microbiological and biochemical analysis that require three working days before obtaining the results (Suzita et al., 2009; Ferdous, 2009). Among several molecular-based techniques, only PCR assay has been useful in detecting V. cholerae based on their gene (Vidal et al., 2007; Keddy et al., 2013). Recently, Srisuk et al. (2010) has reported a new Loop-mediated isothermal Amplification (LAMP) assay which target the same gene with higher sensitivity than simple PCR. It should also be mentioned that PCR assay require expensive equipment and highly skilled personnel, therefore, it is not feasible for small Research Center, Baqiyatallah University of Medical Sciences, 
laboratories as a diagnosis method. Indeed, in control of disease outbreaks, we need a quick and easy method without sacrificing specificity and sensitivity. In this regard, it seems that immunoassay could be the simplest and easy way with enough specificity and sensitivity in recognizing different species of $V$. cholerae. Pensuk and his colleagues have demonstrated a rapid method for diagnosis of various $V$. cholerae based on specific monoclonal antibodies (Pengsuk et al., 2010; 2011; Prompamorn et al., 2013). The aim of this study was to developed mouse monoclonal and rabbit polyclonal antibodies against recombinant OMPw protein that might be useful for immunodiagnostic of $V$. cholerae.

\section{MATERIALS AND METHODS}

\subsection{Immunization of Mice}

Female Balb/c mice aged 6 to 8 weeks old (pasture Institute, Tehran, Iran) were immunized with recombinant OMPw protein.

(MKQTICGLAVLAALSSAPVFAHQEGDFIVRAG IASVVPNDSSDKVLNTQSELAVNSNTQLGLTLGY MFTDNISFEVLAATPFSHKISTSGGELGSLGDIGET KHLPPTFMVQYYFGEANSTFRPYVGAGLNYTTFF DESFNGTGTNAGLSDLKLDDSWGLAANVGFDYM LNDSWFLNASVWYANIETTATYKAGADAKSTDV EINPWVFMIAGGYKF). These recombinant proteins were mixed with equal volume of complete Freund's adjuvant or Incomplete Freund's adjuvant for the first and subsequent interaperitoneal immunization of mice respectively (50 $\mu \mathrm{g}$ protein/Immunization/mouse). One week after the last immunization, blood samples were collected by a vertical incision of the tail vein of mice for determination of antibody titers by ELISA method using HRP goat anti mouse antibody as second antibody. The last injection of $20 \mu \mathrm{g}$ of protein (without any adjuvant) was performed intravenously three days before the cell harvesting.

\subsection{Hybridoma Cell Generation}

Before cell fusion, blood samples of mice were collected and its specific antibody was determined by ELISA method using pre-coated of 96 wells ELISA plates with recombinant OMPw. The mouse with the best antibody titer was selected for cell fusion and hybridoma cell generation. Briefly, Splenocytes from the immunized mice were mixed with murine myeloma $\mathrm{Sp} 2 / 0$ cell line at a ratio of $1: 5$ ( $1 \mathrm{Sp} 2 / 0$ and 5 spleen cells). Cell fusion and selecting hybridoma cell was performed in usual manner. The reactivity of hybridoma supernatants was determined using 96-wells pre-coated ELISA plates (Nunc, Roskilde, Denmark) with $50 \mu \mathrm{L}$ of $10 \mu \mathrm{g} \mathrm{mL}$ of Phosphate-Buffered Saline (PBS) dissolved rOMPw. Finally, positive hybridoma cells were cloned 4 times by limiting dilution to select the stable hybridomas.

\subsection{Ascitic Fluid Production}

Briefly, $0.5 \mathrm{~mL}$ of 2,6,10,14-Tetramethyl pentadecane (Pristane) (Sigma-Aldrich) was injected into peritoneal cavity of Balb/c mice. After one week, $5 \times 10^{6}$ hybridoma cells were washed and re-suspended in $0.5 \mathrm{~mL}$ sterile PBS followed by inoculation into peritoneal cavity of the mice. The ascitic fluids were collected after 7-10 days.

\subsection{Monoclonal Antibody Purification}

Anti rOMPw monoclonal antibodies were affinity purified from ascitic fluid using Hi-Trap protein $G$ column (GE Healthcare, Uppsala, Sweden). Briefly, the ascitic fluids were diluted in 1:5 ratio with PBS and filtered through $0.45 \mu \mathrm{m}$ filters (Orange Scientific, Braine-1' Alleud, Belgium). Elution was performed using 0.1 M Glycine-HCl (pH 2.7). The eluted antibodies were dialyzed against PBS ( $\mathrm{pH} 7.5$ ) overnight at $4^{\circ} \mathrm{C}$. The reactivity of purified antibodies was assessed by ELISA and western blot.

\subsection{Polyclonal Antibody Production}

Two female-white New Zealand rabbits aged 6-8 weeks old (Pasture Institute, Tehran, Iran) were immunized with recombinant OMPw. The first immunization was performed using $50 \mu \mathrm{g}$ protein emulsified in complete Freund's adjuvant and 4 booster injections were performed using $50 \mu \mathrm{g}$ protein emulsified in incomplete Freund's adjuvant. The injections were performed intramuscularly at 4 weeks intervals between the first and second injection and 2 weeks intervals between subsequent injections. Blood samples were collected and polyclonal antibody titers were determined by ELISA as previously described. The specific antibodies were affinity purified by using a column of Hi-Trap protein $G$ column (GE Healthcare, Uppsala, Sweden).

\subsection{Isotype Determination}

The isotype of monoclonal antibodies were determined by isotyping kit goat anti mouse antibody for IgG1, IgG2a, IgG2b, IgG3, IgM and mouse anti goat HRP (Sigma Co.). Briefly, $100 \mu \mathrm{L}$ of hybridoma supernatant was added to each rOMPw pre-coated 96 
wells plate and incubated for $30 \mathrm{~min}$ at $37^{\circ} \mathrm{C}$. After three usual washing, $100 \mu \mathrm{L}$ of each of above mentioned antibodies (diluted 1/1000) was added to respective wells and incubated for further $30 \mathrm{~min}$ at $37^{\circ} \mathrm{C}$. They washed again and $100 \mu \mathrm{L}$ mouse anti goat HRP (diluted 1/100000) were added to each well. Plates were incubated for further $30 \mathrm{~min}$ at $37^{\circ} \mathrm{C}$ and washed again. Substrate (TMB) was added in $100 \mu \mathrm{L}$ volume, incubated in dark room for $25 \mathrm{~min}$. After that stopper solution was added and absorbance was read at 450 using Multiscan ms Labsystem.

Isostrip isotyping kit (mouse monoclonal antibody isotyping kit, Roche Diagnostics, Mannheim, Germany) was also performed for isotyping confirmation. Freshly diluted supernatant (1:10) of the growing hybridomas in $150 \mu \mathrm{L}$ volume was added to the isotyping tubes followed by incubation at RT for $30 \mathrm{sec}$ with gentle shaking. One strip was then inserted in each tube and after 5 min the appearance of a blue band indicated the monoclonal isotype.

\subsection{SDS-PAGE and Western Blot Determination}

Recombinant OMPw was separated using 10\% SDSPAGE gel by electrophoreses system at $50 \mathrm{v}$ for $3 \mathrm{~h}$. In order to visible the separated bands, gels were stained with coomassie brilliant blue R.250 (Sigma). For western blotting, the separated bands of SDS-PAGE were transferred onto nitrocellulose membranes for $1 \mathrm{~h}$ at $100 \mathrm{v}$ or at $15 \mathrm{v}$ for over night using a Trans-blot apparatus (Bio Rad). After that nitrocellulose membrane were incubated with 5\% BSA (sigma) for $30 \mathrm{~min}$ at room temperature, treated with $1 / 100$ purified mouse monoclonal antibodies and incubated for $1 \mathrm{~h}$. Then, Horseradish Peroxidaselabeled (HRP) goat anti mouse IgG antibody (Sigma) was added and incubation was continued for further $1 \mathrm{~h}$ and specific bands were visualized by respective substrate in usual manner. Low and high molecular weight markers standard were developed using coomassie brilliant blue R.250 staining.

\subsection{Identification of $V$. Cholerae Using Agglutination Test}

V. cholerae at $1 \times 10^{8}$ c.f.u/mL was treated with different dilutions (ranging between $1 / 20$ to $1 / 320$ ) of Protein $\mathrm{G}$ purified mouse monoclonal $\mathrm{IgG}$ and rabbit polyclonal antibodies respectively and incubated for two hours at $37^{\circ} \mathrm{C}$. Three other related bacteria; Salmonella, E.coli and Shigella were also treated with above mentioned antibodies dilution looking for any cross reaction. Tubes were centrifuged at $4000 \times \mathrm{G}$ for $5 \mathrm{~min}$ and agglutination was checked in usual manner.

\section{RESULTS}

\subsection{Immune Mice}

The titers of anti-OMPw antibodies in the sera of immunised mice showed that mice number 4 had higher anti-OMPw antibody (Fig. 1). Therefore, this mouse was chosen for further monoclonal antibody production.

\subsection{Anti Recombinant OMPw Monoclonal Antibody}

The screening results showed three clones of monoclonal antibodies against rOMPw. Two out of three clones, D4F10 and D8D6 produced IgG1 and clone A7C5C10 produced IgM. Clone D8D6 had higher OD value (1.80) comparing to D4F11 (1.36) therefore, in this research we followed up our work on clone D8D6 which produced IgG1 monoclonal antibody. The titer of purified antibody of ascitic is shown in Fig. 2. As shown in Fig. 2 mouse monoclonal antibody showed very high absorbance values in ELISA at high dilutions between 1:250 and 1:8000 with recombinant OMPw antigen. The results of isotype identification of monoclonal antibody against rOMPw with iso strip kit showed that produced antibody is $\operatorname{IgG} 2 \mathrm{a} / \mathrm{K}$ (Fig. 3). The specificity of monoclonal antibody to rOMPw was also determined by SDS-PAGE and immuno-blat (Fig. 4 and 5).

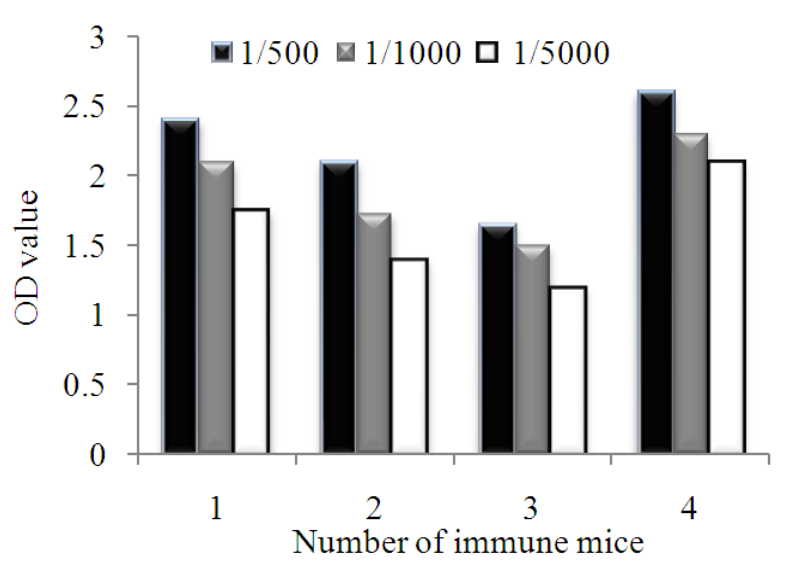

Fig. 1. Titration of specific antibodies against recombinant $\mathrm{OMPw}$ in sera of four Balb/c mice. A serial dilution of immunized mice serum were added to rOMPw pre-coated 96 wells plate and titration of specific antibody was assayed by ELISA method using goat anti mouse antibody conjugated to HRP as secondary antibody (Sigma Co.) 


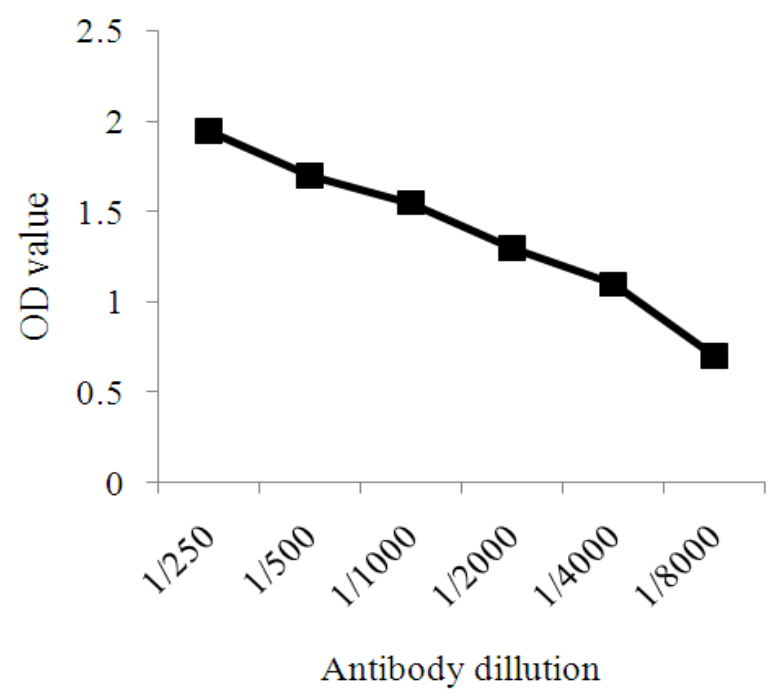

Fig. 2. Titration of specific purified mouse monoclonal antibody against recombinant OMPw. A serial dilution of purified concentrated ascitic liquids among $1 / 250$ to $1 / 8000$ were added to rOMPw precoated 96 wells plate and titration of specific antibody was assayed by ELISA method using isotyping kit goat anti mouse antibody for $\mathrm{IgG1}$, $\operatorname{IgG} 2 \mathrm{a}, \operatorname{IgG} 2 \mathrm{~b}, \operatorname{IgG} 3, \mathrm{IgM}$ and mouse anti goat HRP as secondary antibody(Sigma Co.)

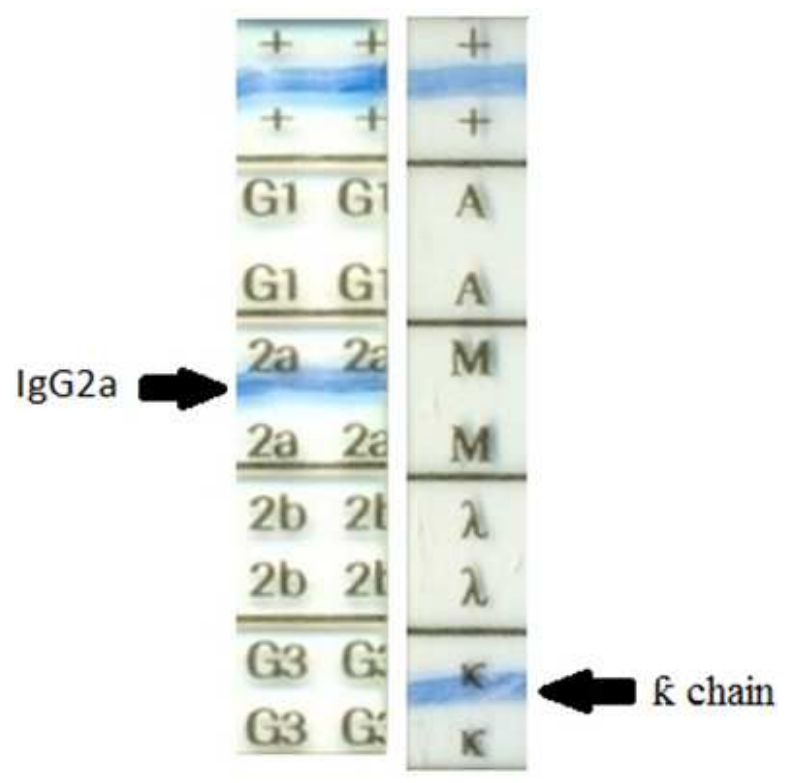

Fig. 3. Isotype identification of monoclonal antibody against rOMPw with iso strip kit (Produced antibody is $\operatorname{IgG} 2 \mathrm{a} / \kappa)$

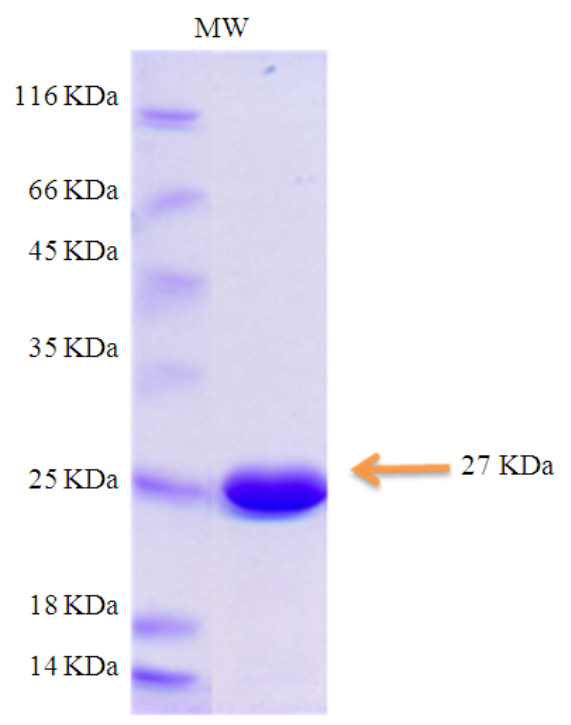

Fig. 4. SDS-PAGE determination of Ag. Recombinant OMPw was separated using $10 \%$ SDS-PAGE gel by electrophoreses system at $50 \mathrm{v}$ for $3 \mathrm{~h}$. The separated bands were stained with coomassie brilliant blue R.250 (Sigma). It showed a band corresponding to $27 \mathrm{KDa}$

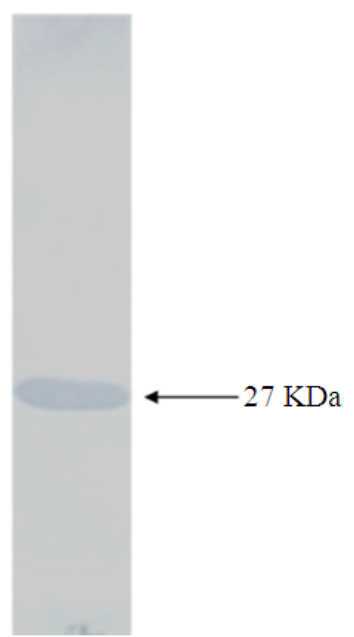

Fig. 5. Western blot determination of mouse purified monoclonal antibody. The separated bands of SDSPAGE were transferred onto nitrocellulose membranes for $1 \mathrm{~h}$ at $100 \mathrm{v}$ or at $15 \mathrm{v}$ for over night using a Transblot apparatus (Bio Rad). After that nitrocellulose membrane were incubated with 5\% BSA (sigma) for 30 min at room temperature, treated with $1 / 100$ purified mouse monoclonal antibodies and incubated for $1 \mathrm{~h}$. Then, Horseradish Peroxidase-labeled (HRP) goat anti mouse IgG antibody (Sigma) was added and incubation was continued for further $1 \mathrm{~h}$ and specific bands were visualized by respective substrate in usual manner. Low and high molecular weight markers standard were developed using coomassie brilliant blue R.250 staining 


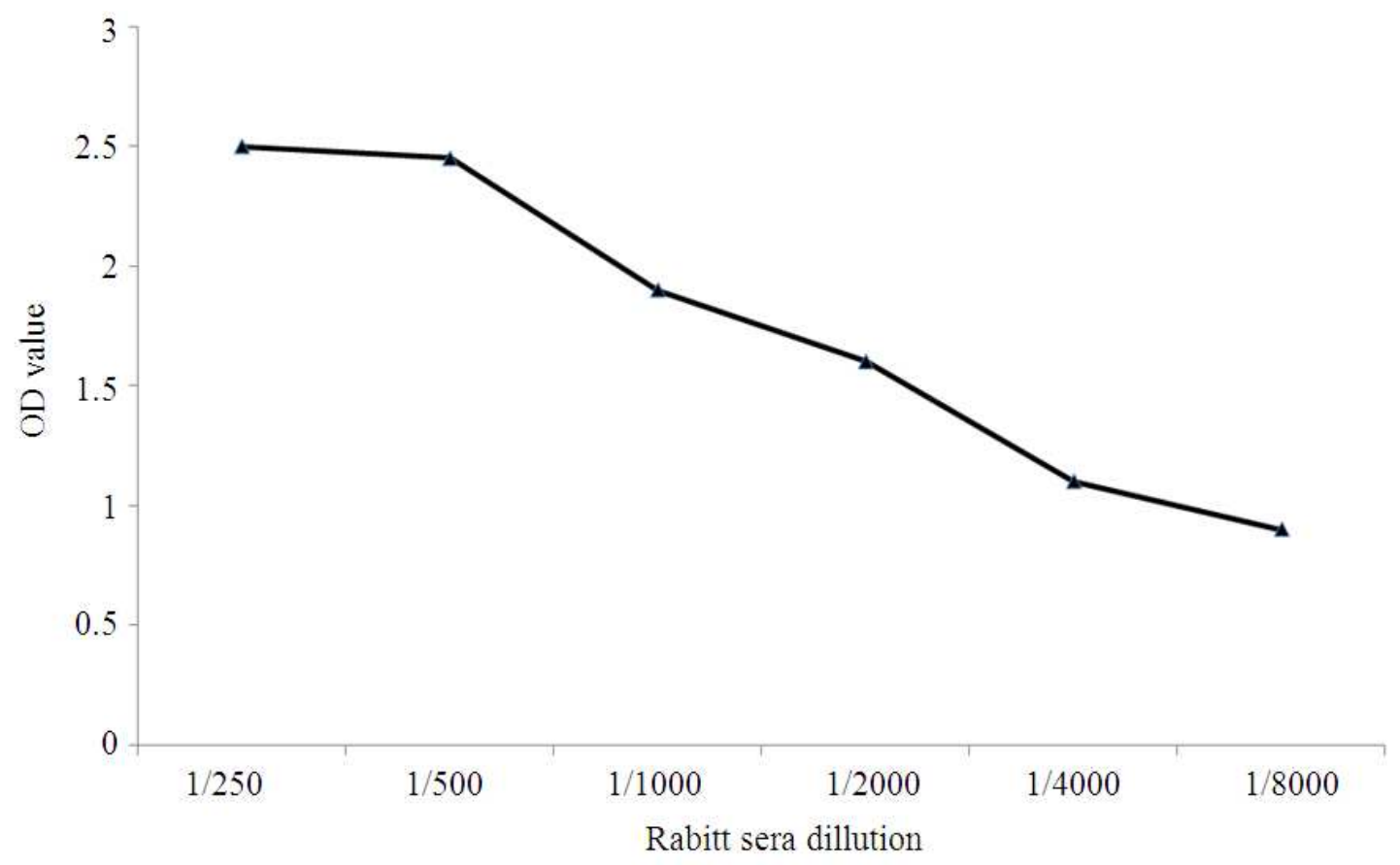

Fig. 6. A serial dilution of immunized rabbit serum were added to rOMPw pre-coated 96 wells plate and titration of specific antibody was assayed by ELISA method using goat anti rabbit antibody conjugated to HRP as secondary antibody (Sigma Co.)

\subsection{Rabbit Anti Recombinant OMPw Polyclonal Antibody}

As shown in Fig. 6 rabbit polyclonal antibodies showed a high absorbance values in ELISA at high dilutions between 1:250 and 1:8000 with recombinant OMPw antigen.

\subsection{Identification of $V$. Cholera and other Bacteria Using Agglutination Test}

The calculation results of agglutination value of both monoclonal and polyclonal antibodies with $V$. cholera and other related bacteria showed that antibodies have been able to agglutinate specific bacteria. Therefore, it means that there has been a reaction between anti recombinant OMPw antibodies with relative molecule on the surface of specific bacteria.

\section{DISCUSSION}

The purpose of this study was to check out if anti recombinant $\mathrm{OMPW}$ antibodies could use as diagnostic for detection of V.cholerae. Our results demonstrated that antibodies recognized specific recombinant OMPw both in ELISA and immunoblat technique. Nevertheless, our antibodies reacted with whole V.Cholerae in agglutination test but not with relative bacteria demonstrating the specificity of anti rOMPw for detection of V.Cholerae.

While, there is similarity and differences between our work to those of others, who immunized their mice with whole bacteria for having hybridoma generation (Pengsuk et al., 2010), but all of them give the idea of possible use of monoclonal antibodies as diagnostic tools in V.Cholerae. They claimed to produce mouse monoclonal antibodies against $V$.Cholerae, then conjugated to gold nanoparticle and used it as immunochromatic strip test for direct detection of $V$. cholerae $\mathrm{O} 139$ in seafood samples. Relative to above study, Pengsuk et al. (2013) also developed a strip test for the detection of V.Cholerae O139 using monoclonal antibodies which specifically bind to the lipopolysaccharide and capsular polysaccharide of $V$. cholerae O139. While in this work we used recombinant OMPw for both immunization of mice and also screening of hybridoma cells for having monoclonal antibodies. In contrast to our work Pengsuk et al. (2010) immunized their mice with five isolates of $V$. cholerae (VC 1, 5, 9,13 and 14) fixed in 4\% Formaldehyde. 
They also reported that the initial screening was done by dot blotting against a mixture of the five isolates of V.cholerae used for immunization. The interesting point is that, they screened their positive cultures by dot blotting and western immunoassay against each of the 5 isolates of $V$. cholerae that were used for the immunization of mice before cell fusion (Pengsuk et al., 2011).

In order to determine whether the antigen which recognized by each monoclonal antibodies in their studies, was a protein or Lipopolysaccharide (LPS), they incubated the used nitrocellulose strip in proteinase $\mathrm{K}$ (Roche, Basel, Switzerland) at 1 unit $\mathrm{mL}^{-1}$ in Tris/ $\mathrm{HCl}$ buffer $(20 \mathrm{mM}, \mathrm{pH} 8)$ containing 1 $\mathrm{mM} \mathrm{CaCl} 2$ for $1 \mathrm{~h}$ at room temperature before subjected to monoclonal antibody. In our experiment anti recombinant $\mathrm{OMPw}$ monoclonal and polyclonal antibodies reacted with whole $V$. Cholerae but not other related bacteria demonstrating the possibility of using anti rOMPw antibodies as a diagnostic tool for detection of $V$. Cholerae.

Our work is also different to those of other scientists who produced anti V.Cholerae monoclonal antibodies (Chaivisuthangkura et al., 2013; Pengsuk et al., 2013). They used two monoclonal antibodies specific to the lipopolysaccharides of Vibrio cholerae O1 Inaba and Ogawa serogroups in order to make an immunochromatographic strip test for direct detection of Vibrio cholerae $\mathrm{O} 1$.

However, in their experiments, they found that detection sensitivities is depended on the material of the other bacteria that could be involved in the growth inhibition of $V$. Cholerae during pre-enrichment step.

In contrast to antibody diagnostic, a multiplex-PCR assay has been developed by (Cherly et al., 2007; Hossain et al., 2013) for the detection of V. cholera through simultaneous amplification of genes.

\section{CONCLUSION}

Our results indicate that anti rOMPw antibodies showed reactivity against whole $V$. cholerae in agglutination test performed in this study. It showed no cross reaction with Salmonella, E.coli and Shigella. However, to further explore reactivity of these antibodies against $V$. cholerae in immunochromatic strip, more studies are suggested. This may elaborate possibility of using the anti rOMPw antibodies in immunochromatic strip test in future.

\section{ACKNOWLEDGEMENT}

This study was supported by grants from Molecular Biology Research Center of Baqiyatallah university of Medical Sciences. We are thankful to Dr. Mostafa Ghanei, Dr. Ali Karami, Dr. Reza Ranjbar and Dr. Hassan Hashemi-Madani for their invaluable advice. We are especially thankful to Dr Mahdi Kamali head of Nanobiotechnology Research Center for his valuable gift of rOMPw.

\subsection{Conflict of Interest:}

The researchers have no conflicts of interest to declare.

\section{REFERENCES}

Chaivisuthangkura, P., C. Pengsuk, S. Longyant and P. Sithigorngul, 2013. Evaluation of monoclonal antibody based immunochromatographic strip test for direct detection of Vibrio cholerae $\mathrm{O} 1$ contamination in seafood samples. J. Microbiol. Methods, 95: 304-311. DOI: 10.1016/j.mimet.2013.09.013

Cherly, L.T., S.P. Jayna, D.P. Nancy, G.S. Evangeline and A.B. Cherly et al., 2007. Identification of Vibrio isolates by a multiplex PCR assay and rpoB sequence determination. J. Clin. Microbiol., 45: 134140. DOI: 10.1128/JCM.01544-06

Ferdous, Z., 2009. Survival of Vibrio cholerae 0139 in association with anabaena variabilis in four different microcosoms. Am. J. Applied Sci., 6: 439444. DOI: 10.3844/ajassp.2009.439.444

Hossain, M.T., Y.O. Kim and I.S. Kong, 2013. Multiplex PCR for the detection and differentiation of Vibrio parahaemolyticus strains using the groEL, tdh and trh genes. Molecular Cellular Prob., 27: 171-175. DOI: 10.1016/j.mcp.2013.04.001

Keddy, K.H., A. Sooka, M.B. Parsons, B.M. NjanpopLafourcade and K. Fitchet et al., 2013. Diagnosis of Vibrio cholerae O1 Infection in Africa. J. Infect Dis., 208: S23-S31. DOI: 10.1093/infdis/jit196

Pengsuk, C., P. Chaivisuthangkura, S. Longyant and P. Sithigorngul, 2013. Development and evaluation of a highly sensitive immunochromatographic strip test using gold nanoparticle for direct detection of Vibrio cholera $\mathrm{O} 139$ in seafood samples. Biosensors Bioelectron., 42: 229-235. DOI: 10.1016/j.bios.2012.10.011 
Pengsuk, C., S. Longyant, S. Rukpratanporn, P. Chaivisuthangkura and P. Sridulyakul et al., 2011. Differentiation among the Vibrio cholerae serotypes O1, O139, O141 and non-O1, non-O139, non-O141 using specific monoclonal antibodies with dot blotting. J. Microbiol. Methods, 87: 224-33. DOI: 10.1016/j.mimet.2011.07.022

Pengsuk, C., S. Longyant, S. Rukpratanpon, P. Chaivisuthangkura and P. Sridulyakul et al., 2010. Development of monoclonal antibodies for simple detection and differentiation of Vibrio mimicus from V.cholerae and vibrio spp. By dot blotting. Aquaculture, 300: 17-24. DOI: 10.1016/j.aquaculture.2009.12.023

Prompamorn, P., S. Longyant, C. Pengsuk, P. Sithigorngul and P. Chaivisuthangkura, 2013. Rapid identification and differentiation of Vibrio parahaemolyticus from Vibrio spp. In seafood samples using developed monoclonal antibodies. World J. Microbiol. Biotechnol., 29: 721-33. DOI: 10.1007/s11274-012-1228-6
Srisuk, C., P. Chaivisuthangkura, S. Rukpratanporn, S. Longyant and P. Sridulyakul et al., 2010. Rapid and sensitive detection of Vibrio cholerae by loopmediated isothermal amplification targeted to the gene of outer membrane protein ompW. Lett. Applied Microbiol., 50: 36-42. DOI: 10.1111/j.1472-765X.2009.02749.x

Suzita, R., A.S. Abdulamir, F.A. Bakar and R. Son, 2009. A mini review: Cholera outbreak via shellfish. Am. J. Infect. Dis., 5: 40-47. DOI: 10.3844/ajidsp.2009.40.47

Vidal, J.E., P. Figueroa-Arredondo, S. Giono-Cerezo, R.M. Ribas-Jaimes and F. Enríquez-Rincón, 2007. Vibrio cholerae O1 strains of different ribotypes have similar hlyA RFLP patterns but different vacuolating ability. Am. J. Infect. Dis., 3: 98-109. DOI: 10.3844/ajidsp.2007.98.109 